\title{
Dalit Literature: A Contemporary Perspective
}

\author{
Mr. Vilas Rupnath Buwa
}

Assistant Professor, Dept. of English, ITGP's Vishwasrao Ransing College, Kalamb-Walchandnagar, Indapur, Dist. Pune, India

\begin{abstract}
As a major literary trend in India through Indian regional languages and translations. Dalit literature is marked for self-assertion of Dalits, subalterns, lower strata of Indian caste-class-religionlanguage-capital ridden society through poetry, plays, short stories, self-narratives, and oral performances challenging inhuman treatment, atrocities, inequality, and the so-called mainstream literary and critical conventions. Dalit literature is emerged as an outcome of the exploitative nature of Indian caste system.The ideology is drawn from Buddha, Charvak, Kabir, JyotiraoPhule, Karl Marx and Dr. B. R. Ambedkar. At this stage, Dalit literature needs to be stabilized at theoretical and critical level, considering western critical approaches in order to explore the essence of Dalit literature on the contemporary literary and critical canvass. This paper attempts to focus onthe term 'Dalit', the elements of Dalit literature, Dalit literature in English, the term 'Dalit identity' and how it reflected in Dalit literature, theorizing Dalit literature and literary critical standards, précising Dalit literature in the recent literary trends in India, comparison and contrast of Dalit literature with the Anglo-American and third world literary tradition, the issues raised by Dalit literature and their validity in the present era, the sources and forces of Dalit literature and future course of Dalit literature.
\end{abstract}

Keywords- Dalit, Dalit consciousness, identity, ideology, caste system etc.

\section{INTRODUCTION}

The term 'literature' is derived from the Latin word Littera, which means letters of the alphabet which denotes that whatever is written or printed is to be called literature. The term 'literature' is used in a very restricted sense or it has a superficial meaning. (Jaaware:2005) Literature is an open-ended linguistic socio-cultural entity. The meanings are extracted from various ways. There are several approaches to make meanings from any literary discourse. The approaches are mainly divided into four categories viz. Author oriented, text oriented, context oriented and reader oriented.

It becomes necessary and appropriate to apply critical evaluative measures and approaches to Dalit literature for the purpose of meaning making because literature contains aesthetic, linguistic, social, cultural and ideological values. Since the Greek tradition, the focus of literary appreciation and criticism has shifted from the author to the text, the content, the context and the readeroriented analysis. There are biographical, social, psychological, structural, archetypal, anthropological, post-structural, modern, post-modern, colonial, postcolonial and aesthetic approaches to interpret literary discourses. The New critical approach and formalism propose the notions of 'art for art's sake' and 'art for life's/society's sake'. The interrelationship between modern and cyber criticism are the germs of meaning making. Edward Said, in his Orientalism (1978) asserts the possibilities of interdisciplinary approach while Barthes, Derrida, Paul de Man, J. Hillis Miller and others stress on the multiplicity of meaning. Norman Holland, Juass, Stanley Fish and Riffaterre have developed the reader centered approach. Dalit Literature needs to be evaluated in relation to its aesthetic, literary, social, and cultural aspects. Therefore, it invites various literary and critical approaches. Any artifact is not alienated from society and therefore, needs to be understood in the context of its social and cultural milieu.

\section{INDIAN LITERATURE IN ENGLISH}

The term 'Indian literature' or 'Indian English Literature' is inadequate to nomenclature. Dalit literature in Indian languages translated in English extends the demographic and linguistic community arena and becomes free to be interpreted at the global level. As it appears in English, it becomes part of English literature which demands or invites the Euro-American critical tradition to appreciate, justify and evaluate its strengths and weaknesses. The notion of Indian literature denotes literary creations in English language by Indians irrespective of their diverse linguistic, literary and sociocultural background. This notion excludes the literary creations or artefacts in Indian languages as the result of colonial and elite ideology. Despite of idiosyncrasies of the term 'Indian English Literature' it was marked for 'Indianness' reflected in literary artefacts. Extending the same notion of distinctiveness or uniqueness is applied to Dalit literature and dalitness in Dalit literature

\subsection{Indian Dalit Literature:}


The literary creations by the writers who are born and brought up in Dalit communities are called Dalit literature. The literary creations are generated with a purpose of change. It is a tool for socio-cultural change in the caste-ridden Indian society. Dalit literature follows the notion of 'Art for Life's Sake'. Regarding Dalit literature JanardanWaghmare, the eminent scholar observes the major characteristics of Dalit literature for its distinctiveness as:

...it is committing, collective and
contemporaneous. It is the literature of the ex-
untouchables of our country who were, like the
American Blacks, socially estranged, culturally
alienated, economically exploited, physically
annihilated and psychologically mutilated and
were kept for centuries in their "place" which
was, of course, at the bottom of the Hindu
society. (64:2001)

In a Key Note Address Raj Rao, the eminent scholar and creative writer divides Indian literature in five categories: Indian literature by upper castes, Dalit literature, Diasporic literature, Gay and Lesbian literature and Women literature. He rightly points out that Dalit literature is originated in Indian Regional languages and mainly in Marathi.

...their own literature that we today know as Dalit Sahitya. While this literature is not (or not yet) written in English but in native Indian languages, the work of prominent Dalit writers like NamdeoDhasal, Laxman Gaikwad, Laxman Mane and SharankumarLimbale is available today in English translation. (Rao)

A Dalit writer born and brought up in Dalit community possesses Dalit consciousness or sensibility. Though some of the literary forms, novels and plays depict the protagonist as Dalit but it lacks Dalit consciousness. Mulk Raj Anand's novel does not depict Dalit consciousness because it carries Gandhian philosophy rather than Buddhism and Ambedkarism. Raj Rao regards it as:

The Dalit's refused to call Untouchable a Dalit novel, and Tendulkar's Kanyadaan a Dalit play, although the protagonists here were Dalit, because the upper caste authors of these works were voiceappropriating outsiders. (Rao)

The representation is at the level of sympathy only and hence it lacks Dalit sensibility. Identity is the major issue of Dalit literature and therefore, Rao further comments as:

In our new formulation of an identity-based literature, as opposed to a national literature, we have already spoken of Dalit Sahitya, though not originally written in English, as being no different ideologically from diaspora literature, gay and lesbian literature, and women's writing. What these literatures have in common is their resistance to the idea of a centre, whatever that centre be. (Rao)

Thus, the categorization or classification is based on the degree of exploitation.

In this era of economic and social globalization, Dalit literature is recognized as the voice of the erstwhile untouchable communities from their rage against inequality, urge for humanity. Black literature, Caribbean literature proved their identity. The multilingual and multicultural nation like India has proved that caste system is one of the means of exploitation. The earlier 'exoticness' of India progressed towards reality. Francophone literature and the exploitation of the black community in France have been brought forward by Franz Fanon, AimeCesaire, and Senghor. Indian novelists like R.K. Narayan, Mulk Raj Anand and Raja Rao produced Indian literature in English. The African - American literature is distinguished for certain features. In the same manner the sufferings of Dalit communities are brought forward by Dalit literature and needs to be evaluated by separate standards or measures.

The ideological, literary and theoretical sources of Dalit literature are mainly derived from AfricanAmerican literature, Harlem Renaissance, Black Panther Movement, Dalit Panther Movement, the struggle for establishing or proving identity as human being, Marxist social values, class struggle, the struggle against untouchability, seeking education, the ideological traits mainly of Buddha, Charvak, JyotiraoPhule, King Shahu, Dr. B.R. Ambedkarand the subaltern perception of identity.Dalit literature is a democratic literary movement emerged in order to uproot untouchability, caste and gender discrimination and to demand equal opportunities in every field of life. Dalit Panther and several other Dalit organisations are the examples. The representation of Dalits in literature of the elites by the upper caste writers is scrutinized and how Dalit and Non-Dalit writers have portrayed Dalits either with empathy or sympathy or caricaturing. The essence of Dalit literature is Dalit Consciousness which is explained as:

The Dalit consciousness in Dalit literature is the revolutionary mentality connected with struggle. It is a belief in rebellion against the caste system, recognizing the human being as its focus. Ambedkarite thought is the inspiration for this consciousness. Dalit consciousness makes slaves conscious of their slavery. Dalit consciousness is an important seed for Dalit literature; it is separate and distinct from the consciousness of other writers. Dalit literature is demarcated as 
unique because of this consciousness. (Limbale: 32)

Identity, aesthetics, language, style, themes, forms and contexts are the major is sues of Dalit literature. It is also evident that the available theoretical, literary and critical approaches and methods, either oriental or occidental are needed to be applied for appreciating and interpreting Dalit literature. The existing conventional Indian literary theory is inadequate as it is based on Hinduism and the sanskritized literary and critical conventions. Applying the so-called Indian and Western theory is also an effort of interpretation but at the same time such application of theory is inadequate and only then the possibilities of new and distinctive interpretations of Dalit literature is possible. It is an attempt to explore various aspects of Dalit literature.

\section{THE DISTINCTIVENESS OF DALIT LITERATURE:}

Dalit individuals or communities are productive and creative in every field of life. Dalit literature is a creation which proclaims the agenda of better and tolerable life which is distinctive. Irfan Habib, points out the distinctiveness of Dalit literature as:

Dalit literature, a new and unique phenomenon in Marathi letters, is characterised by protest and revolt; and the sensibility of the Dalit writer, like the sensibility of the Black American writer, has made him an iconoclast as well as a creator. It cannot be understood and interpreted without a socio-anthropological approach. The suffering of the Indian pariahs is the theme of the Dalit literature. The life of the pariah has always been a source of universal suffering which has now found its expression in the Dalit writing. And the suffering of the Dalit person does not remain individual. It is the suffering of the whole Dalit society. The suffering assumes a personality of its own in the writing of the Dalit writer. The Dalit writer's commitment is to bring about a social change by waging a war against the caste untouchables to live in the basement of social and cultural life. The Dalit writer wants a cultural revolution in India. (66:2001)

Thus, Habib points out or highlights the characteristics of Dalit literature that it is literature of protest and revolt of Dalit sensibility and the role of Dalit writer as well.

SharankumarLimbale defines Dalit literature as:

By Dalit literature, I mean writing about Dalits by Dalit writers with a Dalit consciousness. The form of Dalit literature is inherent in its Dalitness, and its purpose is obvious: to inform
Dalit society of its slavery, and narrate its pain and suffering to upper caste Hindus. (18)

Limbale further comments on the role of Dalit writers as: Only dalit writers have narrated the pain of Dalits-this is as true as the fact that rural writers have not depicted the life of Dalits. This defines the limit of the rural writers. (28)

The creation of Dalit literature is intended. It has its own function though it a poem, novel, play, short story or narrative. The role Dalit literature further highlights as:

Dalit literature is precisely that literature which artistically portrays the sorrows, tribulations, slavery, degradation, ridicule and poverty endured by Dalits. This literature is but a lofty image of grief. (2010:30)

Every human being must find liberty, honour, security, and freedom from intimidation by the powerful elements of society. These values are now being articulated in a particular kind of literature- its name being Dalit literature. Recognizing the centrality of the human being, this literature is thoroughly saturated with humanity's joys and sorrows. It regards human beings as supreme, and leads them towards total revolution. (Limbale: 2010:30)

Thus, the role of Dalit literature, Dalit writers and the notion of ideology behind Dalit literature are significant in the era of globalisation.

\section{THE ESSENCE OF DALIT LITERATURE}

Dalit consciousness is the core concern of Dalit literature. The literary creation must explore 'Dalit sensibility'. Dalit consciousness is the intended notion or idea which includes the role of Dalit literature, Dalit writer, Dalit sensibility, Dalitness and come with certain solution of protest and revolt against exploitation of Dalit individuals and communities. Caste, class, demography gender etc. are the means of exploitation of Dalits attributed with the notion of 'purity' in the caste Hindu elites.

The Dalit consciousness in Dalit literature is the revolutionary mentality connected with struggle. It is a belief in rebellion against the caste system, recognizing the human being as its focus. Ambedkarite though is the inspiration for this consciousness. Dalit consciousness makes slaves conscious of their slavery. Dalit consciousness is an important seed for Dalit literature; it is separate and distinct from the consciousness of other writers. Dalit literature is demarcated as unique because of this consciousness. (32) 
Marathi literature, Dalit literature stood for universal freedom. The word Dalit did not denote caste; rather, it referred to those who were yesterday's exploited and were now fighting back. Thus, while the neo-Buddhist writers have ridiculed the word Dalit, Dalit writers have embraced it. Today, the term Dalit has acquired a new dimension, it does not seem appropriate for neo-Buddhist writers to criticize it. (42)

Thus, the word 'Dalit' is originated in Marathi and spread all over the world.

\section{THE ROLE OF DALIT WRITERS}

Among the four major components, author, text, context and reader, author is the pivotal one in the process of literary creation. An author is expressed through his or her literary creations. He/she is not innocent because he/she comes and gets reflected with his or her sociocultural background. In context of Dalit writer, Dalit is the person using the power of expression is born and brought up in Dalit caste and having experienced of exploitation through the means of caste, class, gender, patriarchy etc. He or she has assumed a certain role of social reformation through literary expressions. A creator is exhibited in his or her creation. William Wordsworth in his Preface to Lyrical Ballads stated the role of a poet(writer) that he must communicate in the language of people and comment on the common subject. Irfan Habib, the eminent historian and critic attributes the role of a Dalit writer as:

The Dalit writer wants to change it; he does not want it to be in future what it was in the past and what it is in the present. His creative energy is taken up and exhausted by his confrontation with his "dalitness". He is in the same position as the Black American writer has been. His "Dalitness", like the Negro's "Blackness", keeps him always in a mental tension. (65:2001)

Thus, 'Dalit literature' refers to or denotes the empathic literary creations, as a part of social upheavals of Dalit movement by the writers having 'Dalit consciousness' to create a new world which is revolutionize in every field of life based on equality, anti-casteist ideology, anti-gender discrimination, demanding equal opportunity, demanding the identity as a human being and status of Indian society through the various literary forms being inspired by the Buddhism, Bhakti movement, Marxist philosophy and the Phule-Shahu and Ambedkarite ideology. Dr.BabasahebAmbedkar's struggle to eradicate untouchability is reflected in the formation of the Indian constitution which became the pivotal part of Dalit movement that brought an individual identity to each and every Dalit in India.

\section{CASTE, CLASS, GENDER, RELIGION AND PATRIARCHY}

Caste is the major divisive factor of Indian society. The characteristics of caste are: Heredity, Marriage restrictions, traditional occupation, Dietary rules, and Hierarchy. It is the major divisive factor through which dominance exists. Regarding the existence of caste Limbale comments as:

The period from the rise of Buddhism (c.500BC) to the Gupta age (fourth and fifth centuries AD) may, then, be supposed to be the period of the formation of the Indian caste system and its supporting 'ideology'. (2010:169)

He further comments:

Caste, we may say, is a fairly well-marked, separate community, whose individual members are bound to each other through endogamy (and hypergamy), and very often also by a common hereditary profession or duty, actual or supposed. (2010:161)

Dalit literature stands against the rigidity of caste system which snatches the opportunities of equality in every field of life and thus becomes an instrument of exploitation. It is supported by religion i.e. Hinduism and the images of Dalits are proposed in negative sense. Dalit literature takes stand against untouchability imposed via religion. Through religion, and caste hierarchical patriarchy plays a crucial role in exploitation of women. Dalit literature also takes firm stand against it.

The pivotal issue regarding Dalit literature is that the writer and the text cannot be separated. A reader's interpretation may be varied on the basis of either he or she belongs to Dalit community or elite caste. The caste is the major factor which brings exploitation for Dalit communities in India and the Dalit writers who write about their sufferings and exploitation cannot be separated because they both areinterdependent emphatically.

The mainstream British literature has been glorified by the Scottish, Irish, Welsh, American, Third world literature, Indian literature etc. The contextual notions such as Marxist, psychological, archetypal, colonial and postcolonial, and feminism have changed the canons of literary criticism. Dalit literature needs to be revaluated, judged, and criticized from the global point of view which shatters the early concepts: 'Dalit', Dalit literature, subaltern literature, Dalit writers, and Dalit readers and so on. 


\section{CONCLUSION}

In this era of economic and social globalization, Dalit literature is recognized as the voice of the erstwhile untouchable communities from their rage against inequality, urge for humanity. Black literature, Caribbean literature proved their identity. The multilingual and multicultural nation like India has proved that caste system is one of the means of exploitation. The earlier 'exoticness' of India progressed towards reality. Francophone literature and the exploitation of the black community in France have been brought forward by Franz Fanon, AimeCesaire, and Senghor. Indian novelists like R.K. Narayan, Mulk Raj Anand and Raja Rao produced Indian literature in English. The African - American literature is distinguished for certain features. In the same manner the sufferings of Dalit communities are brought forward by Dalit literature and needs to be evaluated by separate standards or measures.

The study of Dalit literature is significant in the era of $21^{\text {st }}$ century because it has distorted the canon of literature and literary critical theory in India and abroad. The voices of the subsidiary and deprived communities from all over the world and their reflection through literature need to be given space in the mainstream because literature is cantered of 'human being' and it is the role and function of literature to offer human society on the equal footage to everyone and eradicate the stains of inhumanity on the basis of caste, creed, religion, race, ethnicity and so on. As the earlier slave community in America, though lost their language, history, culture, struggled for their rights and created a new culture such as jazz and established identity in America. In the same manner, it becomes necessary to consider Dalit literature by applying various approaches and find out separate standards of evaluation for better humanity.

\section{REFERENCES}

[1] Ahmad, AijazIn Theory: Classes, Nations, Literatures Verso, 1992

[2] Ambedkar, B.R. Writings and Speeches, Vol. I. Mumbai: Govt. of Maharashtra1979.

[3] Ashcroft, Bill, Gareth Griffiths and Helen Tiffin Post-Colonial Studies Routledge, London and New York 2000, rpt.2007

[4] Bagul, Baburao. "Dalit Literature is but Human Literature". Dangle, Arjun (ed.) Poisoned Bread: Translations from Modern Marathi Dalit Literature. New Delhi: Orient Blackswan 2009

[5] Dangle, Arjun (ed.) Poisoned Bread: Translations from Modern Marathi Dalit Literature. New Delhi: Orient Blackswan 2009

[6] Fanon, Frantz Black Skin, White Masks, Pluto 1952
[7] Fanon, Frantz The Wretched of the Earth Penguin, 1961, 1967

[8] Gaikwad, LaxmanThe Branded, Translated by P.A. Kolharkar. New Delhi: Sahitya Akademi 1998

[9] Gaikwad, Laxman. Uchalya, Pune: Srividya Prakashan 1987

[10] Habib, Irfan. Essays in Indian History New Delhi: Tulika Books, (1995) 2010

[11] Karhade, Sada. DaliltSahityaChikitsa Aurangabad: SwarupPrakashan 2001

[12] Kamble, Baby Jina Amucha, Pune: Rachna Prakashan 1986

[13] Kamble, Baby The Prisons We Broke, Translated by Maya Pandit. New Delhi: Orient Blackswan.2009

[14] Keer, Dhanajay. Dr.Ambedkar: Life and Mission $3^{\text {rd }}$ edn. Bombay: Popular Prakashan 1987

[15] Kirawale, Krishna. BaburaoBagul New Delhi: SahityaAkademi 2012

[16] Limbale, SharankumarAkkarmashi, Pune: Srividya Prakashan 1984

[17] Limbale, SharankumarThe Outcaste, Translated by Santosh Bhoomkar. New Delhi: Oxford University Press 2003

[18] Limbale, Sharankumar. 1996. Towards an Aesthetics of Dalit Literature. Tr. By Mukherjee, Alok. (2004.) Hyderabad: Orient Longman.

[19] Omvedt, Gail. Dalit Visions New Delhi: Orient Blackswan, 2006

[20] Omvedt, Gail. Understanding Caste $2^{\text {nd }}$ edn New Delhi: Orient Blackswan, 2011

[21] Omvedt, Gail. "Dalit Literature in Maharashtra: Literature of Social Protest and Revolt in Western India." South Asian Bulletin 1987

[22] Patil, Sharad. Abrahmani Sahitache Saundaryashastra Pune: SugawaPrakashan 1988 New Delhi: Indus. 1960, rpt. 1995

[23] Shah, G. (ed.) Dalit Identity and Politics. Vol. II. Delhi: Sage Publications, 2001.

[24] Shirvadkar, Keshav. Marxwadi Sahityavichar Pune: Continental Prakashan, 1980

[25] Spivak, GayatriChakravorty. 'Can the Subaltern Speak? 1993

[26] Waghmare, Janardan. The Quest for Black Identity Pune: SugavaPrakashan, 2001

[27] Zelloit, Eleanor. From Untouchable to Dalit. Delhi: Manohar, 1996. Print. 